mediastudies.press • Social Media \& the Self: An Open Reader

\title{
The Looking-Glass Self
}

Charles Horton Cooley

Published on: Jan 01, 1902

License: Creative Commons Public Domain Dedication (CC-0 4.0). 
THAT THE "I" of common speech has a meaning which includes some sort of reference to other persons is involved in the very fact that the word and the ideas it stands for are phenomena of language and the communicative life. It is doubtful whether it is possible to use language at all without thinking more or less distinctly of someone else, and certainly the things to which we give names and which have a large place in reflective thought are almost always those which are impressed upon us by our contact with other people. Where there is no communication there can be no nomenclature and no developed thought. What we call "me," "mine," or "myself" is, then, not something separate from the general life, but the most interesting part of it, a part whose interest arises from the very fact that it is both general and individual. That is, we care for it just because it is that phase of the mind that is living and striving in the common life, trying to impress itself upon the minds of others. "I" is a militant social tendency, working to hold and enlarge its place in the general current of tendencies. So far as it can it waxes, as all life does. To think of it as apart from society is a palpable absurdity of which no one could be guilty who really saw it as a fact of life.

The reference to other persons involved in the sense of self may be distinct and particular, as when a boy is ashamed to have his mother catch him at something she has forbidden, or it may be vague and general, as when one is ashamed to do something which only his conscience, expressing his sense of social responsibility, detects and disapproves; but it is always there. There is no sense of "I," as in pride or shame, without its correlative sense of you, or he, or they. Even the miser gloating over his hidden goals can feel the "mine" only as he is aware of the world of men over whom he has secret power; and the case is very similar with all kinds of hid treasure. Many painters, sculptors, and writers have loved to withhold their work from the world, fondling it in seclusion until they were quite done with it; but the delight in this, as in all secrets, depends upon the sense of the value of what is concealed.

In a very large and interesting class of cases the social reference takes the form of a somewhat definite imagination of how one's self-that is any idea he appropriatesappears in a particular mind, and the kind of self-feeling one has is determined by the attitude toward this attributed to that other mind. A social self of this sort might be called the reflected or looking-glass self:

Each to each a looking-glass

Reflect the other that doth pass 
As we see our face, figure, and dress in the glass, and are interested in them because they are ours, and pleased or otherwise with them according as they do or do not answer to what we should like them to be; so in imagination we perceive in another's mind some thought of our appearance, manners, aims, deeds, character, friends, and so on, and are variously affected by it.

A self-idea of this sort seems to have three principal elements: the imagination of our appearance to the other person; the imagination of his judgement of that appearance; and some sort of self-feeling, such as pride or mortification. The comparison with a looking-glass hardly suggests the second element, the imagined judgment, which is quite essential. The thing that moves us to pride or shame is not the mere mechanical reflection of ourselves, but an imputed sentiment, the imagined effect of this reflection upon another's mind. This is evident from the fact that the character and weight of that other, in whose mind we see ourselves, makes all the difference with our feeling. We are ashamed to seem evasive in the presence of a straightforward man, cowardly in the presence of a brave one, gross in the eyes of a refined one, and so on. We always imagine, and in imagining share, the judgments of the other mind. A man will boast to one person of an action-say some sharp transaction in trade-which he would be ashamed to own to another.

\section{EXCERPT}

Human Nature and the Social Order (Charles Horton Cooley, Charles Scribner's Sons, 1902: 149, 151-53)

PUBLIC DOMAIN 